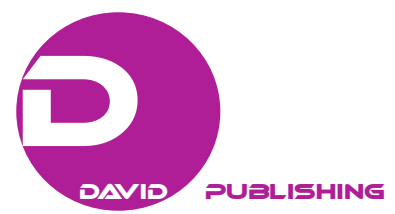

\title{
Correlating Customer Satisfaction and Customer Loyalty: The Case of International Tourists in Cretan Resort Hotels
}

\author{
Vasiliki Avgeli \\ MBS College of Crete, Crete, Greece \\ Dimitris Smarianakis \\ Marios Sotiriades \\ Ningbo University, Ningbo, China
}

\begin{abstract}
Customer satisfaction and customer loyalty are considered as a confirmation of remarkable service provision towards the customers. The formation of both constructs is viewed as a vital element which leads to the reinforcement of competitive advantage for the hotels. Various academic viewpoints are available concerning the constructs of customer satisfaction and loyalty; nevertheless, most of them indicate an opposition towards their correlation. The aim of this research was to investigate the factors that reinforce the satisfaction and loyalty levels of resort tourists and identify whether or not the two constructs are interrelated. A quantitative research methodology was applied, with the use of close-ended paper questionnaires, which were administered to international tourists staying in resort hotels in the Municipality of Hersonissos, one of the most popular tourist destinations in northern Crete. Findings confirmed a positive correlation between customer satisfaction and customer loyalty. Data also showed that food and beverage quality, location and price are considered as the most significant factors that enhance satisfaction levels, whereas emotional experiences, loyalty programs, customer service quality, and customer satisfaction were identified to have a significant impact on the formation of customer loyalty.
\end{abstract}

Keywords: customer satisfaction, customer loyalty, correlations, international tourists, resort hotels

\section{Introduction}

The concepts of customer satisfaction and customer loyalty are considered as two concepts that assist on the reinforcement of hotel operation and performance (Farquahar, 2013, as cited in Chinomona \& Dubihlela, 2014). Various academics have recognized principal drivers that have repercussions on customer satisfaction (Lu, Berchoux, Marek, \& Chen, 2015; Ren, Qiu, Wang, \& Lin, 2016). Research related to resort hotels and customer satisfaction is limited, while only Channoi, Clemes, and Dean (2018) examined the way customer satisfaction, customer loyalty along with service quality can contribute towards the achievement of long-standing and high engagement resort hotel visits.

In our days, where the continuous development of the Internet appears to affect businesses and more specifically hotels, academics have started to examine a broad range the factors that lead to customer satisfaction

\footnotetext{
Vasiliki Avgeli, Dr., Academic Principal/lecturer, Business \& Tourism Department, MBS College of Crete, Crete, Greece. Dimitris Smarianakis, M.Sc., International Hotel \& Tourism Management Department, Ningbo University, Ningbo, China. Marios Sotiriades, Prof., Business School, Ningbo University, Ningbo, China.
} 
and relate to hotels in regards to online customer feedback (Zhao, Xu, \& Wang, 2019; Xu, 2020). Kim, Lee, and Joun (2016) discussed the correlation between green acts that are applied by hotels, with customer satisfaction, while all of the information used was acquired from the company's online feedback platform. A more recent study by Sukhu, Choi, Bujisic, and Bilgihan (2019) mainly emphasized on reviewing and identifying which hotel service factors wield influence on customer satisfaction along with emotional responses during the tourist's visit.

In relation to customer loyalty, contemporary research emphasizes on the application of loyalty programs by hotels, in exchange for competitive advantage (Nastasoiu \& Vandenbosch, 2019; Pesonen, Komppula, \& Murphy, 2019). Additionally, other researchers have supported an association among customer loyalty and emotional experiences (Ali, Kim, Li, \& Jeon, 2018; Heesup, Kiattipoom, \& Wansoo, 2019). The prevailing interrelation of customer satisfaction and customer loyalty has become a highly contradicted case, where academics and researchers either endorse or reject the potential connection between the two concepts (Skogland \& Siguaw, 2004; Chiguvi \& Guruwo, 2015).

The aim of this research is to explore the factors that cause customer satisfaction to international tourists in Cretan resort hotels (Hersonissos Municipality) and whether these customer satisfaction factors have a correlation or not with customer loyalty. More specifically, it focuses on identifying whether customer satisfaction factors can affect or even induce customer loyalty. Studies regarding customer satisfaction and loyalty have never been carried out in resort hotels in Crete, Greece, thus it is considered important to respond to this context gap, as the hotel industry in Greece is of paramount importance given the fact it is accountable for the 20\% of the country's Gross Domestic Product (WTTC [World Travel Tourism Council], 2018). Subsequently, the final results from this research will also contribute as guidance towards the hotel professionals in pursuance of enhancing the overall guest experience.

\section{Literature Review}

\section{Customer Satisfaction and Customer Loyalty}

There is a prevailing interrelation among customer satisfaction, retention, and profitability. Hence, customer satisfaction is reflected as a criterion for favorable business outcomes (Hill \& Alexander, 2006). Customer satisfaction is viewed as a customers' post consumption judgment towards the services or products of a business (Quan, 2010; Gupta \& Bansal, 2012). Several authors assert that customer satisfaction has a direct impact on the financial outcomes of a brand (Grigoroudis, Tsitsiridi, \& Zopounidis, 2013; Keisidou, Sarigiannidis, Maditinos, \& Thalassinos, 2013; Sun \& Kim, 2013). Consequently, customer satisfaction can be considered as a marketing tool for the measurement of the relationship among the brand and its customers (Heinonen, 2014).

Customer loyalty provides companies with competitive advantage which is sustainable in the course of time (Setó-Pamies, 2012). The conceptual definition of customer loyalty depends on a group of four dissimilar factors (Pitta, Franzak, \& Fowler, 2006). Firstly, it is formed by "trust" where customers demonstrate reliance and faith towards the brand, service, or product. Secondly, it is affected by the perceived value of the products/services, which needs to be in excess of what the competitors offer. Additionally, it is characterized by "emotional bond" which is expressed by the customer being committed and attached to the brand while being insusceptible to switching to another brand or product. Lastly, "customer intimacy" which relates to "making customers feel good whenever they make contact with a company" (Pitta et al., 2006, pp. 422-424). Various academics support the view that trust and commitment are the two most significant influences for customer 
loyalty (Bagram \& Khan, 2012; Gallarza \& Saura, 2006; Hallowell, 1996).

\section{Customer Satisfaction and Customer Loyalty in the Hospitality Industry}

The achievement of customer satisfaction is considered as vitally important, as the survival, continuity and financial performance of hotels are formed and determined by it (Deng, Sinha, \& Zhao 2017). Customer satisfaction could be described as the end-state vision that hotels focus on pursuing, due to the long-lasting advantages, such as favorable reputation, customer loyalty along with sustainable rate of return (Liu \& Jang, 2009). Wicks and Roethlein (2009) suggested that customer satisfaction refers to providing services that develop particular levels of sensed value for the visitor, so that he/she continues to be favorably committed to the hotel.

High levels of customer satisfaction lead to the attraction of new customers, financial performance increase, along with the potential distribution of recommendations based on post consumption reviews and impressions (U. Ramanathan \& R. Ramanathan, 2010; Bartikowski \& Llosa, 2007). The positive impacts of attaining customer satisfaction and customer loyalty are conspicuous given the fact that remarkable quality services are essential for the enhancement of the hotels' demand, which in turn leads to improved financial performance (Sun \& Kim, 2013; Kesari \& Atulkar, 2016). Furthermore, the degree of customer satisfaction is mostly composed by buildup experiences which occur in the course of contact with the hotel (Santouridis \& Trivellas, 2010).

Customer satisfaction is deemed to be an indispensable constituent which wields influence on the sustainability and survival of a hotel (Ren et al., 2016). Zeithaml and Bitner (2003) pointed out that the higher the quality of the service, the more satisfied the customer is, while a variety of factors assist visitors to evaluate the quality of the provided services within the hotels (Wilkins, Merrilees, \& Heringtoon, 2007). Several authors suggest that offering outstanding value to customers, which originates from the overall experience with the service, represents a significant way of attaining customer satisfaction and possibly customer loyalty (Gallarza \& Saura, 2006; Kesari \& Atulkar, 2016).

Despite the fact that hotel companies apply loyalty schemes that include rewards with a purpose of maintaining customers, there is limited knowledge (Nastasoiu \& Vandenbosch, 2019; Kwiatek \& Thanasi-Boçe, 2019) regarding the ways of retaining the hotels' guest portfolio (W. Chen \& M. Chen, 2014). Achieving customer loyalty precipitates long standing connections of the hotels with their customers (Pan, Sheng, \& Xie, 2012) and unconditional devotion towards the hotel without being tempted and induced by similar competitor offers (So, King, Sparks, \& Wang, 2013). Additionally, a major loyal customer attribute relates to the willingness of paying more for the provided services and products and concurrently being reluctant to switching to another hotel brand (Evanschitzky et al., 2012). Keller (2003) described customer loyalty as a mental devotion towards the provider of specific services or products which is maintained by repetitive purchases in the course of time.

Considering the significance of customer loyalty and its several benefits towards the hotel companies, several hotel brands have developed and applied reward and loyalty schemes in pursuance of attracting and retaining new customers (Tanford, Raab, \& Kim, 2012). However, more empirical evidence need to be provided in order to verify the long lasting consequences of loyalty schemes along with their performance and efficiency (Liu, 2007), therefore this sets the need for further research in the future.

\section{Determinants of Customer Satisfaction and Customer Loyalty}


Given the significance of customer satisfaction towards the success of hotel brands, various academics focused on distinguishing customer insights regarding products or services provided by hotels, along with the impacts of such insights on customer satisfaction (U. Ramanathan \& R. Ramanathan, 2010). Albayrak and Caber (2015) investigated customer satisfaction, using nine different drivers; results showed that personnel and food and beverage quality were identified to have the largest impact on customer satisfaction. Moreover, Mohsin and Lockyer (2010) claimed that the quality of reception services and room services along with remarkable restaurant quality, highly likely wield influence towards customer satisfaction. Additionally, the quality of the physical facilities and equipment alongside with staff's behavior, revealed a favorable effect on the levels of customer satisfaction (Ekinci, Daves, \& Massey, 2008). Similarly, Yang and Lau (2015) agreed that room quality and overall services are highly imperative for the formation of customer satisfaction. Slevitch and Oh (2010) acknowledged that core-related drivers (e.g., purity, bed/pillows, order and safety, and front desk services) and facility-related drivers (e.g., customized services, public areas and amenities, sauna, and complementary snacks) were identified in their research to be extremely significant towards the attainment of customer satisfaction. Based on online reviews of five-star hotels, it was identified that favorable comments were referring to the rooms, personnel, food, services, and hotel location, while worth noting is the fact that room upgrades, late checkouts, and free bus service towards the airport, were also viewed as significant factors that enhanced the guest's gratification on Malaysian resort hotels (Khoo-Lattimore \& Ekiz, 2014; Ali, 2015).

Customer satisfaction can be influenced to a high extent by the professional manners of the staff, the hotel's provided conveniences, whereas room suitability, the location of the hotel and its nearness to a shopping area can be considered as determinants by which certain guests can be satisfied (Wu, Pearce, \& Dong, 2017). In addition, transfer towards and off the hotel unit, wine and dine quality, quality-price ratio, front desk services and overall interior design \& decoration are viewed as drivers that exert influence towards the visitors' anticipations, hence to their satisfaction levels ( $\mathrm{Li}, \mathrm{Ye}, \&$ Law, 2012). Corporate image could also wield influence on perceived value and customer satisfaction; while at the same time, it can possibly induce loyalty (Ryu, Han, \& Kim, 2008). Survey results conducted in Turkish luxury hotels, revealed that facilities and conveniences, as well as hotel design were viewed as the most imperative characteristics regarding the physical hotel environment, while employee professionalism, thoughtfulness and behavior towards the customers were identified as the most momentous qualities that affected the overall experience (Cetin \& Walls, 2016).

Seven highly significant drivers were introduced by Gu and Ryan (2008) regarding bed comfort, hygiene and immaculateness of the bathroom, size and state of bedroom amenities, hotel accessibility, wine and dine quality, assistance services, along with employee performance, all of which affect the formation of customer satisfaction. Approximately one decade later, Ren et al. (2016) divided the available drivers into named categories, such as tangible and sensorial experience, staff performance, aesthetic perception, and hotel location. A recently introduced determinant of customer satisfaction was identified by Wong, Leung, and Law (2015) who indicated that a well-designed mobile website can be nowadays considered vital for satisfying the guests' needs.

The drivers that wield influence towards customer loyalty have been broadly reviewed by academics and professionals (Wang, 2010; Allaway, Huddleston, Whipple, \& Ellinger, 2011), as they are viewed as highly significant for the attainment of comparative advantage and sustainable outcomes (Berezan, Raab, Yoo, \& Love, 2013). According to Phi, Thanh, and Viet (2018), customer loyalty can be influenced by four dissimilar characteristics of service quality, namely, reliability (customer service quality), responsiveness (helpful staff), website utilities (properly structured website which guides and directs the customers through the available 
services and transactions), and tangibles (hotel amenities). Several determining factors of customer loyalty are comprised by physical environment activities, emotional events together with the entire hotel image (Hwang, Han, \& Kim, 2015; Ryu, Lee, \& Kim, 2012). Every emotional experience related to the hotel, general hotel image and customer satisfaction, can wield influence on customer loyalty (Heesup et al., 2019).

Existing research has determined various factors that affect customer loyalty and incorporate the perceived appreciation for the brand (Chen \& Hu, 2010), staff manners and participation (Saks, 2006), conception of the brand image (Wang, 2010), build of trust towards the hotel brand by the customer (Choi \& La, 2013), benefits emerging from the customer-hotel association (Chen \& Hu, 2010) as well as, the build of rapport between the staff and the tourists (Delcourt, Gremler, Riel, \& Birgelen, 2013). Research conducted in UK hotels revealed that value for money is an essential determinant that could induce customer loyalty and the customers' intention to revisit the same hotel, while "customer service", "room quality", and "food and beverage quality" were found to impact unfavorably the customers' loyalty and revisit intentions if they were provided on an insufficient level (U. Ramanathan \& R. Ramanathan, 2010). Furthermore, reward and loyalty programs are determined as an imperative driver of customer loyalty (Tanford, Raab, \& Kim, 2010). Finally, service quality can have an imperative role in forming the visitors' loyalty towards the hotel (Shifera \& Apar, 2015).

\section{Correlation of Customer Satisfaction and Customer Loyalty}

Various researchers have demonstrated indispensable connections between customer satisfaction and customer loyalty, whereas additional investigations have depicted simply a weak linkage (Bolton, 1998). Skogland and Siguaw (2004) outlined that customer satisfaction does not necessarily lead to repetitive purchases and the return of customers, hence their study revealed only a minor connection among customer satisfaction and customer loyalty. Additionally, Bennet and Rundle-Thiele (2004) indicated that customer satisfaction and customer loyalty inside the hotel service setting are viewed as dissimilar constructs, and regardless of the favorable connection found by other academics, high satisfaction levels do not mandatorily bring about customer loyalty.

A contrary aspect was depicted by El-Adly (2018) who supported the view that customer satisfaction is positively associated and impacts customer loyalty. Additionally, a recent study indicated the favorable interrelation among satisfaction and loyalty and ended up with the viewpoint that the management of hotels must pay thorough attention so as to fulfil their customers' requirements in order to achieve comparative advantage and therefore result in customer loyalty (Raouf-Ahmad \& Jyoti, 2017).

In contrast, customer loyalty is thought as an unstable state, hence it cannot assure the fact that current loyal customers will not indicate switching behaviors in the occasion of top quality services being offered by alternative hotel brands (Mohsan, Nawaz, Khan, Shaukat, \& Aslam, 2011). Kandampully and Suhartanto (2000) revealed that there is no available framework that focuses entirely on the measurement of customer loyalty or the detection of drivers that induce loyalty, hence they concluded that the presumption of satisfaction being a loyalty antecedent is inconsistent.

In addition, Tsai and Haung (2007) supported that customer satisfaction is an antecedent of revisit intentions, as customer satisfaction can possibly wield influence upon building relationships among the customer and the hotel brand (Ndubisi, Malhotra, \& Chan, 2009). Quite the reverse, Gremler and Brown (1996) had supported that customer satisfaction is a crucial driver of customer loyalty, but their correlation is contradictory. Moreover, older researchers have concluded that customer satisfaction can be a predominant driver for impelling customer 
loyalty (Anderson \& Fornell, 1994; Pritchard, 1991, as cited in Gremler \& Brown, 1996). Other studies have indicated that customer satisfaction is not adequate to shape loyal customers (Cronin \& Taylor, 1992; Fornell, 1992).

\section{Methodology}

The methodological approach of this research was based on quantitative research methods. More specifically, a survey was conducted with the use of structured questionnaires, which were distributed to international tourists in resort hotels in the area of Hersonissos. Questions were developed working deductively from general to specific. It should be noted that the review of the literature played a significant role in research planning, questionnaire development, and design stages, as it became an input to the planning, design, and analysis of the questionnaires. The questionnaires employed for the purpose of this research contained closed questions. They were easier and quicker to complete, the quantification and coding were easier, and there was the possibility to ask more questions in relation to the time and money available (Brunt, 1997).

The sampling methods that have been applied are Convenience Sampling \& Purposive or Judgment Sampling. Convenience sampling enabled the researcher to select a part of the population that met specific criteria. Purposive sampling enabled the researcher to select on purpose the sample based on certain peculiarities. Purposive sampling is developed by the researcher, based on what must be examined; therefore, the sample is selected appropriately (Ilker Sulaiman, \& Rukayya, 2016). The sample for this research involved international tourists (excluding Greek nationals) regardless of ethnicity over the age of 18 years, who were all guests in resort hotels within the municipality of Hersonissos in Crete.

Data were collected through the allocation of 400 close-ended paper questionnaires on 16 resort hotels located within the municipality of Hersonissos in Crete. The distribution of questionnaires started on the 15th of July 2019, while the research lasted for one month over the period of 20th July 2019-20th August 2019. The questionnaires were given to guests by the guest relation managers, as this was asked from the resort hotels. Questionnaires were distributed during breakfast time and also inside the guests' rooms. From 400 distributed questionnaires, 227 were answered, and finally 172 questionnaires were valid.

\section{Limitations}

The major limitation in this research involved the sample size, since there were questionnaires that were not answered (from 400 questionnaires that were distributed 173 questionnaires were returned Blanc). Another limitation that had an impact on the sample size was the denial from management to distribute questionnaires within two resort hotels, along with the $0 \%$ response rate from another three resort hotels. Consequently, this sample would not be completely objective, as the number of participants is small compared to the total market (Charters \& Ali-Knight, 2002). Although the sample concerns international tourists, the research is limited by its exploratory nature and in particular because it took place in a specific part of Greece.

\section{Results}

\section{Profile of Respondents}

Half of the sample, $50 \%$ were classified as male, while $48 \%$ were categorized as female. The rest $2 \%$ preferred not to answer.

Regarding the age groups, $32 \%$ was between the ages of $35-44$ years, $30 \%$ was $45-54$ years old, another $15 \%$ was among 25-34 years old, $14 \%$ were above 55 years old and finally a 10\% was between the ages of 18-24 years. 
Data showed that $31 \%$ of the respondents had a Bachelor degree and another $31 \%$ had a Master degree. High school was completed by $26 \%, 9 \%$ had completed a doctorate degree, while $3 \%$ stated that they had a high school diploma.

There were $26 \%$ of the respondents who stated that their income was above $€ 50 \mathrm{k}$. Another $23 \%$ stated that their income was in the range of $€ 30 \mathrm{k}-€ 39 \mathrm{k}$. Additionally, $18 \%$ of the respondents ranged between $€ 40 \mathrm{k}$ and $€ 49 \mathrm{k}$, while $17 \%$ stated $€ 20 \mathrm{k}-€ 29 \mathrm{k}$. Lastly, 6\% stated that their income was below $€ 10 \mathrm{k}$.

As presented in Figure 1, 30\% of respondents were from the United Kingdom, followed by $16 \%$ of German tourists. French and Russian tourists amounted accordingly 9\%. The sample consisted of tourists from another 22 countries with percentages less than 5\%, as presented in Figure 1.

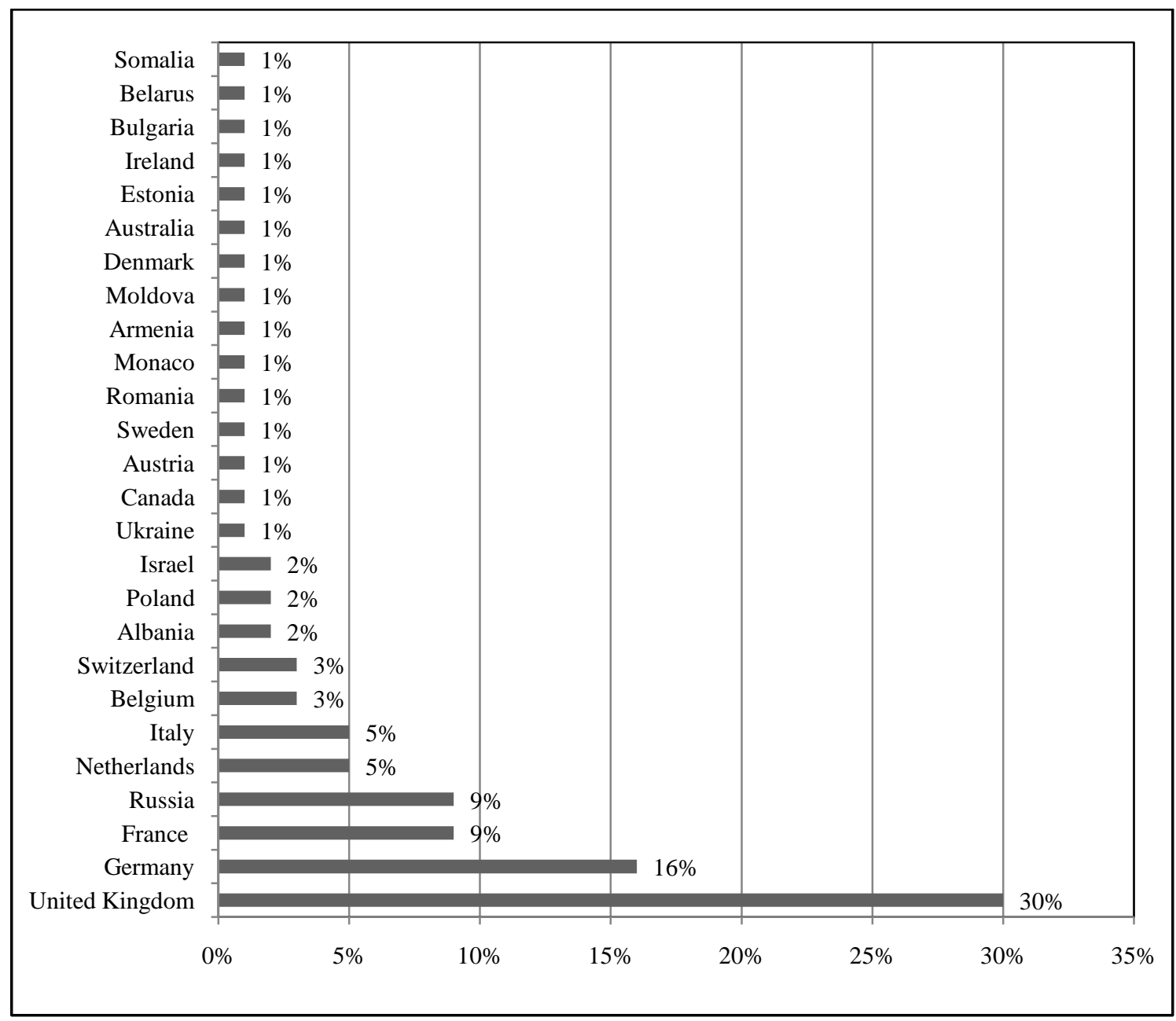

Figure 1. Country of origin.

\section{Section 1: General Questions}

The main purpose of travel/stay at the chosen hotel was "holiday/recreation" for $94 \%$ of the respondents. The variable "family/friends visit" was chosen by $3 \%$ of the respondents. On a similar level, $2 \%$ of the respondents visited Crete and the hotel for business reasons and $1 \%$ chose the "other" variable, specifying that the purpose of travel was based on a necessity to get a visa.

More than half of the respondents, a 74\% stated that this was the first time they visited this particular hotel, 
while $26 \%$ indicated that they have visited this hotel in the past.

Half of the respondents, $53 \%$ stated that this was not the first time they were visiting the island of Crete, whereas for $47 \%$ this was the first time.

The final questions of the introductory section aimed to get a first insight of the sample's beliefs regarding the relation between satisfaction and loyalty. The results indicated that $84 \%$ of the respondents consider themselves as loyal customers given that their satisfaction is achieved. On the contrary, $16 \%$ of respondents reported that they do not always feel loyal when they are satisfied.

Finally, $89 \%$ of the respondents agreed that they felt satisfied during the state of being loyal. A contradicting view was presented by $11 \%$ who stated that they do not always consider themselves satisfied during the state of being loyal customers. The purpose of these two opposite questions was to verify the positive or negative correlation among the two concepts of customer satisfaction and customer loyalty.

\section{Section 2: Customer Satisfaction and Loyalty}

The next question aimed to identify the four most significant factors that lead to satisfaction during the tourists' stay at the resort hotels. The four most significant factors, according to the samples responses regarded food and beverage quality (16\%), location (14\%), price (10\%), and finally well-trained staff/behaviour (8\%). Figure 2 presents all the factors that were included in the sample's answers with the percentages of choice.

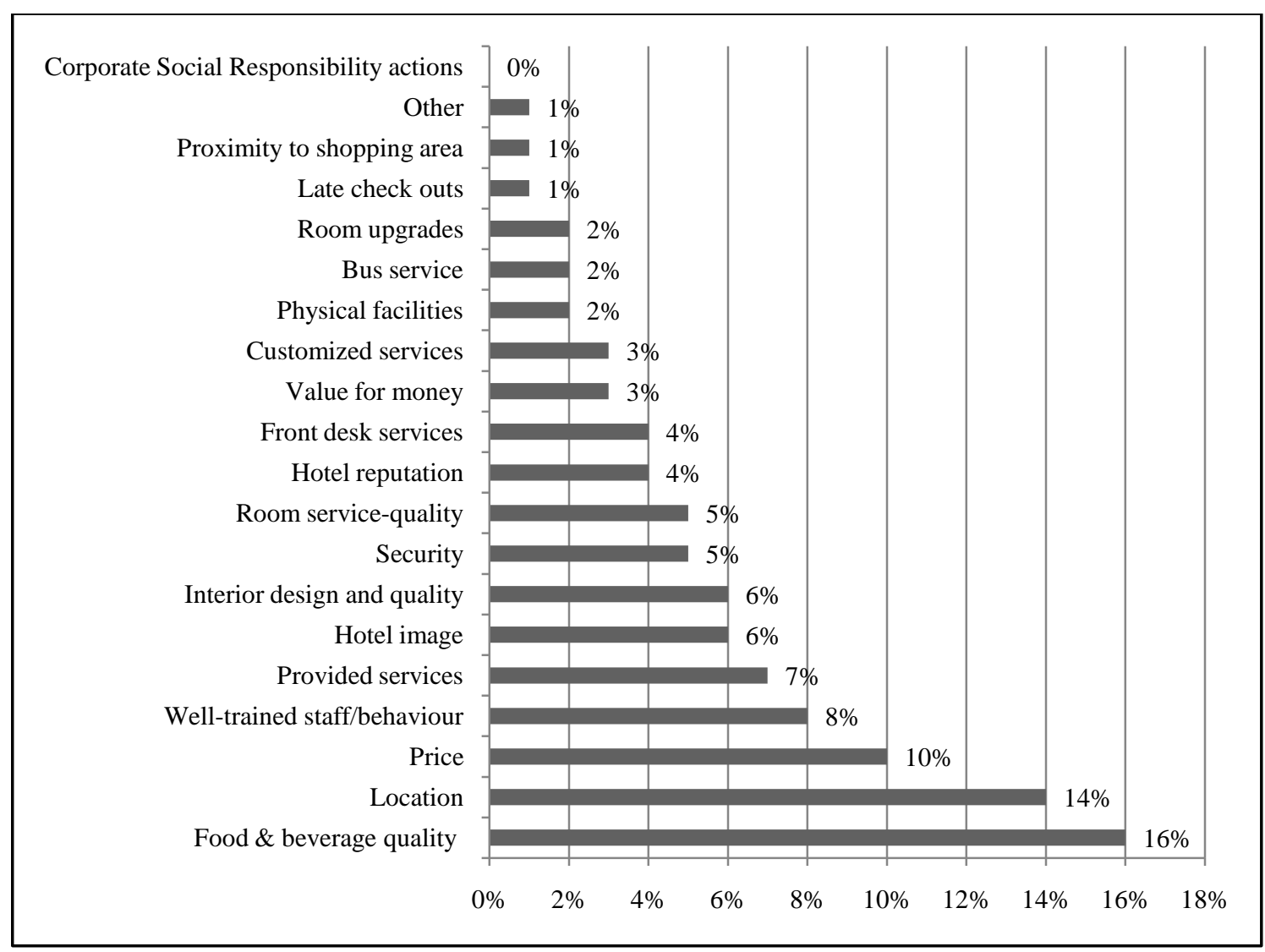

Figure 2. Customer satisfaction factors.

The next question investigated the most important factors that affect the sample's attitude and intention to return to this particular hotel. According to the data, $16 \%$ stated that their loyalty towards the resort hotel 
depends on emotional experiences, $13 \%$ chose loyalty programs, another $13 \%$ noted customer service quality, and $12 \%$ claimed that customer satisfaction impacts on their loyalty level. Figure 3 presents all the factors that were included in the sample's answers with the percentages of choice.

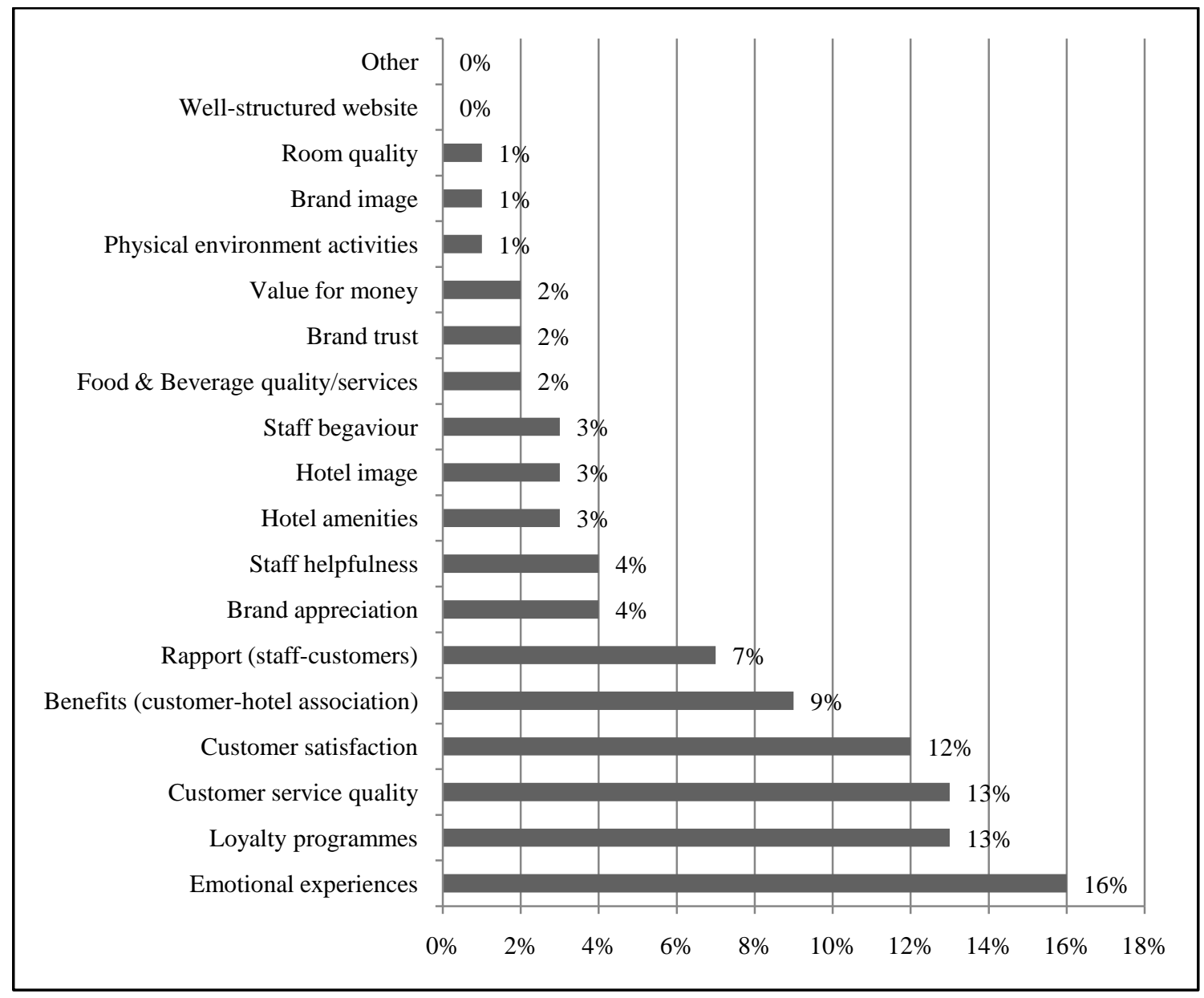

Figure 3. Customer loyalty factors.

\section{Section 3: Likert Scale Questions}

The analysis of Likert Scale questions has been conducted by measuring the mean so as to acquire a vision and perspective of the central tendency of the respondent's answers. The mean has been measured on a range from 1 to $5(1=$ "Not satisfied/No affect/Extremely unlikely/Not at all loyal" and $5=$ "Extremely satisfied/Major affect/Extremely likely, extremely loyal").

The first Likert scale question involved the extent to which specific factors affected the sample's decision to choose the particular hotel they were staying, which is presented in Table 1 . The food and beverage quality presented a mean of 4.52 , indicating a major effect and the highest score as a factor. Room quality \& size, provided services, and location of the resort hotel displayed a mean of 4.25, 4.25, and 4.22, respectively, indicating a slightly lower score. A moderate impact involved hotel reputation, value for money, and positive reviews, as they had a mean of $4.08,4.06$, and 4.02 , respectively. The security factor revealed a mean of 3.68 , and previous experience was proved to have a neutral impact on their decision with a mean of 2.98 .

The next issue involved room quality factors based on the respondent's satisfaction level during their stay, 
in order to obtain an overview. Respondents seemed to express a similar opinion regarding the factors of room services, room cleanliness, room suitability-convenience and room amenities, revealing a similar mean of 4.20, $4.24,4.23$, and 4.20 accordingly, as it can be observed in Table 2 .

Table 1

Rate the Extent to Which the Following Reasons Affected Your Decision to Choose This Hotel

\begin{tabular}{|l|c|}
\hline \multicolumn{1}{|c|}{ Factors } & Mean (Central Tendency) Range: 1-5 \\
\hline Price & 3.75 \\
Location & 4.22 \\
Security & 3.68 \\
Hotel reputation & 4.08 \\
Positive reviews (word-of-mouth) & 4.02 \\
Provided services & 4.25 \\
Food \& Beverage quality (All-inclusive or not) & 4.52 \\
Room quality \& size & 4.25 \\
Value for money & 4.06 \\
Previous experience & 2.98 \\
\hline
\end{tabular}

Table 2

Rate the Extent to Which You Are Satisfied With the Following Room Quality Factors

\begin{tabular}{|l|c|}
\hline \multicolumn{1}{|c|}{ Factors } & Mean (Central Tendency) Range: 1-5 \\
\hline Room services & 4.20 \\
Room cleanliness & 4.24 \\
Room suitability - convenience & 4.23 \\
Room amenities (Size \& quality) & 4.20 \\
\hline
\end{tabular}

Respondents also assessed the degree to which they remained satisfied with staff related factors during their stay. As presented in Table 3, staff friendliness presented a mean of 4.67, staff behavior (4.65), staff responsiveness (4.64), and staff professionalism (4.63), showing that customers are extremely satisfied. Lastly, staff skillfulness-competencies revealed a mean of 4.50, ranging between the "very" and "extremely" satisfied rate.

Table 3

Rate the Extent to Which You Are Satisfied With the Following Staff Related Factors 


\begin{tabular}{|l|c|}
\hline \multicolumn{1}{|c|}{ Factors } & Mean (Central Tendency) Range: 1-5 \\
\hline Staff behaviour & 4.65 \\
Staff professionalism & 4.63 \\
Staff skilfulness - Competencies & 4.50 \\
Staff friendliness & 4.67 \\
Staff responsiveness & 4.64 \\
\hline
\end{tabular}

Respondents were also asked to indicate their satisfaction levels regarding the general services provided during their stay at the resort hotels. As Table 4 illustrates, a mean of 4.44 indicated that respondents were very satisfied with food and beverage quality, followed by front desk services (4.32). Safety and security along with speedy services were measured to have a mean of 4.19 and 4.16 respectively. In addition, within the very satisfied range were the factors of physical facilities, customized services, and public area amenities with means 4.02, 4.01, and 4.02, respectively. Room upgrades were slightly lower, with a mean of 3.96, showing that customers were almost very satisfied with them. The three factors with the lowest measurements involved the quality of mobile website, late checkouts, and bus service, whose mean was measured as 3.80, 3.70, and 3.64 , respectively, therefore the central tendency was ranging among the moderately satisfied and very satisfied.

Table 4

Rate the Extent to Which You Are Satisfied With the Following General Services

\begin{tabular}{|l|c|}
\hline \multicolumn{1}{|c|}{ Factors } & Mean (Central Tendency) Range: 1-5 \\
\hline Front desk services & 4.32 \\
Physical facilities & 4.44 \\
Customized services & 4.02 \\
Public area amenities & 4.01 \\
Room upgrades & 4.02 \\
Late checkouts & 3.96 \\
Bus service & 3.70 \\
Quality of mobile website & 3.64 \\
Safety \& Security & 3.80 \\
Speedy services & 4.19 \\
\hline
\end{tabular}

Respondents were also asked to assess their satisfaction, regarding the overall services provided from the hotel they were staying. Results showed that respondents were very satisfied with the services provided $($ Mean $=4.31)$.

Respondents rated the possibility of returning to the same hotel. The central tendency through the 
measurement of the mean as 4.20 revealed that the specific tourists were likely to return back.

As far as their loyalty was concerned, results showed that respondents considered themselves very loyal $($ Mean $=4.03)$.

\section{Gender Connected With Satisfaction and Loyalty}

The connection between gender and the extent of satisfaction which arose from the overall hotel services, provided some interesting findings, showing that male respondents (47) were "Very satisfied", while female respondents who were "Very satisfied" were slightly lower (36). As presented in Table 5, for the "Extremely satisfied" option, most responses were reported by female respondents (41), whereas 29 male respondents were extremely satisfied. Results show that gender does not impact the satisfaction factor as a similar number of female (77) and male (76) respondents are "Very satisfied" and "Extremely satisfied".

Gender was also assessed in connection to loyalty, providing similar results with satisfaction, as presented in Table 6.

Table 5

Gender Overall Service Satisfaction

\begin{tabular}{|c|c|c|c|c|c|c|}
\hline \multirow{2}{*}{ Gender } & \multicolumn{5}{|c|}{ How satisfied are you with the hotel's overall services? } & \multirow{2}{*}{ Total } \\
\hline & Not satisfied & Slightly satisfied & Moderately satisfied & Very satisfied & Extremely satisfied & \\
\hline Male & 0 & 1 & 9 & 47 & \begin{tabular}{|l|}
29 \\
\end{tabular} & 86 \\
\hline Female & 0 & 0 & 5 & 36 & 41 & 82 \\
\hline Prefer not to say & 0 & 0 & 2 & 1 & 1 & 4 \\
\hline Other & 0 & 0 & 0 & 0 & 0 & 0 \\
\hline Total & 0 & 1 & 16 & 84 & 71 & 172 \\
\hline
\end{tabular}

Table 6

Gender Loyalty Extent to Hotel

\begin{tabular}{|l|c|c|c|c|c|c|}
\multirow{2}{*}{ Gender } & \multicolumn{5}{|c|}{ Please rate the extent to which you consider yourself as loyal to this hotel } & \multirow{2}{*}{ Total } \\
\cline { 2 - 6 } & Not at all loyal & Slightly loyal & Moderately loyal & Very loyal & Extremely loyal & \\
\hline Male & $\mathbf{2}$ & $\mathbf{3}$ & 13 & 32 & 36 & 86 \\
\hline Female & 1 & 1 & 18 & 39 & 23 & 82 \\
\hline Prefer not to say & 1 & 0 & 2 & 1 & 0 & 4 \\
\hline Other & 0 & 0 & 0 & 0 & 0 & 0 \\
\hline \multicolumn{1}{r|}{ Total } & 4 & 4 & 33 & 72 & 59 & 172 \\
\hline
\end{tabular}

\section{Age Connected With Satisfaction and Loyalty}

Another demographic variable, age, was also connected with satisfaction and loyalty. As Table 7 presents it is interesting to note that most of the respondents who consider themselves as a loyal customers when they are satisfied with the hotel's overall services were between the ages of 35-44 years and 45-54 years.

Table 7

Age Satisfaction to Loyalty Connection

\begin{tabular}{|l|c|c|c|}
\multirow{2}{*}{ Age } & \multicolumn{2}{|c|}{ When you are satisfied with a hotel's overall services, do you consider yourself as a loyal customer? } & \multirow{2}{*}{ Total } \\
\cline { 2 - 4 } & Yes & No & 17 \\
\hline $18-24$ & 14 & 3 & 25 \\
\hline $25-34$ & 21 & 4 & 55 \\
\hline $35-44$ & 48 & 7 & 51 \\
\hline $45-54$ & 45 & 6 & 24 \\
\hline $55+\quad 16$ & 8 & 172 \\
\hline
\end{tabular}




\section{Correlations}

The Pearson correlation coefficient was utilized to measure the significance of a linear connection among the data that occurred from particular questions. The correlations were calculated using Microsoft Office Excel and produced results ranging from -1 to +1 . The range from -1 to +1 can indicate a positive, negative, or no correlation among the examined data.

Initially, the two variables that were measured in order to examine whether there was a prevalent correlation between them involved the "extent of satisfaction with room quality factors" and the "extent of satisfaction with staff related factors". Based on the primary results, the measurement of Pearson's $r$ has been calculated as $r=0.82$, a result which highlighted the high positive linear relationship among the data of the two questions.

The next set of factors that was measured involved the "extent to which respondents were likely to return to the same hotel" and the "extent to which they consider themselves loyal to the hotel they were staying". Through Pearson's $r$ measurement the correlation coefficient was $r=0.97$, a result that pinpointed as well a very high positive linear relationship among the set of two questions.

Lastly, the two factors that were correlated were "when respondents are satisfied with the hotels' overall services, do they consider themselves loyal" and "when respondents consider themselves loyal, do they feel fully satisfied". The measurement of Pearson's $r$ was $r=1$, an interesting finding which revealed a perfect positive linear relationship regarding the respondents' viewpoints relating to these two questions.

\section{Conclusion}

The aim of this research was to investigate the connection between the terms of customer satisfaction and customer loyalty. Following this aim, an effort has been made to identify the factors that can lead to satisfaction and loyalty, while trying to identify the most significant ones and distinguish the factors that can lead specifically to the formation of each of the two terms. The overall aim was to clarify the ambiguous connection of the terms discussed by several academics and elucidate whether customer satisfaction can induce customer loyalty or if it is simply the same.

The findings of this research included the identification of significant factors that assist on the formation of customer satisfaction (food and beverage quality, location, and price) and customer loyalty (emotional experiences, loyalty programs, customer service quality, and customer satisfaction), whereas it has been revealed that customer satisfaction is positively correlated to customer loyalty. Therefore, this implies that when satisfaction levels increase, the same applies for loyalty levels. This particular research differentiated its purpose to the point where it identified separately the factors that indicated the highest importance and impact both on customer satisfaction and customer loyalty, in order to produce a distinct overview of them. Additionally, this research focused specifically on resort hotels, thus the findings might not apply to other hotel types.

The emerged implications of this research can be used by hotel industry professionals around the world, but more specifically resort hotels around Crete in order to formulate their service provision based on data that has been indicated through the viewpoints of the respondents that participated in this research. Additionally, tourist operators who work in partnership with resort hotels in Crete could demand from the hotels to meet certain service provision standards; therefore, they can assure that customer satisfaction is achieved, so that both sides, the hotel/tourist operator and the customers remain satisfied, indicate enhanced possibilities of 
returning back.

\section{Recommendations}

An interesting recommendation would be to re-conduct this research during the winter season and specifically within a large variety of city and boutique hotels. Following this, a detailed comparison could be made in order to produce a clear understanding of the similarities and differences between different types of tourists, hotels and season, so that a general overview of the ideal service provision around Crete could be identified. Furthermore, the same research could be conducted once again following the methodology of mixed methods by distributing questionnaires to tourists and conducting interviews with resort hotel managers in order to identify the tourists' perceptions regarding satisfaction and loyalty.

\section{References}

Albayrak, T., \& Caber, M. (2015). Prioritisation of the hotel attributes according to their influence on satisfaction: A comparison of two techniques. Tourism Management, 46, 43-50.

Allaway, A. W., Huddleston, P., Whipple, J., \& Ellinger, A. (2011). Customer-based brand equity, equity drivers, and customer loyalty in the supermarket industry. Journal of Product \& Brand Management, 20(3), 190-204.

Ali, F. (2015). Service quality as a determinant of customer satisfaction and resulting behavioural intentions: A SEM approach towards Malaysian resort hotels. Tourism, 63(1), 37-51.

Ali, F., Kim, W. G., Li, J., \& Jeon, H. M. (2018). Make it delightful: Customers' experience, satisfaction and loyalty in Malaysian theme parks. Journal of Destination Marketing \& Management, 7, 1-11.

Anderson, E. W., \& Fornell, C. (1994). A customer satisfaction research prospectus. In R. T. Rust and R. L. Oliver (Eds.), Service quality: New directions in theory and practice (pp. 241-268). Thousand Oaks: Sage Publications.

Bagram, M., \& Khan, S. (2012). Attaining customer loyalty: The role of consumer attitude and consumer behavior. International Review of Management and Business Research, 1(1), 1-8.

Bartikowski, B., \& Llosa, S. (2007). Customer satisfaction measurement: Comparing four methods of attribute categorizations. Service Industries Journal, 24(4), 67-82.

Bennett, R., \& Rundle-Thiele, S. (2004). Customer satisfaction should not be the only goal. Journal of Services Marketing, 18(7), 514-523.

Berezan, O., Raab, C., Yoo, M., \& Love, C. (2013). Sustainable hotel practices and nationality: The impact on guest satisfaction and guest intention to return. International Journal of Hospitality Management, 34, 227-233.

Bolton, R. N. (1998). A dynamic model of the duration of the customer's relationship with a continuous service provider: The role of satisfaction. Marketing Science, 17(1), 45-65.

Brunt, P. (1997). Market research in travel and tourism. Oxford: Butterworth-Heinemann.

Cetin, G., \& Walls, A. (2016). Understanding the customer experiences from the perspective of guests and hotel managers: Empirical findings from luxury hotels in Istanbul. Journal of Hospitality Management \& Management, 25(4), 395-442.

Channoi, R., Clemes, M., \& Dean, D. (2018). A comprehensive hierarchical model of beach resort hotel stays. Journal of Hospitality and Tourism Management, 37, 107-116.

Charters, S., \& Ali-Knight, J. (2002). Who is the wine tourist? Tourism Management, 23, 311-319.

Chen, W., \& Chen, M. (2014). Factors affecting the hotel's service quality: Relationship marketing and corporate image. Journal of Hospitality Marketing \& Management, 23(1), 77-96.

Chen, P., \& Hu, H. (2010). The effect of relational benefits on perceived value in relation to customer loyalty: An empirical study in the Australian coffee outlets industry. International Journal of Hospitality Management, 29(3), 405-412.

Chiguvi, D., \& Guruwo, P. T. (2015). Impact of customer satisfaction on customer loyalty in the banking sector. International Journal of Scientific Engineering and Research, 5(2), 55-63.

Chinomona, R., \& Dubihlela, D. (2014). Does customer satisfaction lead to customer trust, loyalty and repurchase intention of local store brands? The case of Gauteng Province of South Africa. Mediterranean Journal of Social Sciences, 5(9), 23-30.

Choi, B., \& La, S. (2013). The impact of corporate social responsibility and customer trust on the restoration of loyalty after service failure and recovery. Journal of Services Marketing, 27(3), 223-233. 
Cronin, J., Jr., \& Taylor, S. A. (1992). Measuring service quality: A re-examination and extension. Journal of Marketing, 56, 55-68.

Delcourt, C., Gremler, D., Riel, A., \& Birgelen, V. M. (2013). Effects of perceived employee emotional competence on customer satisfaction and loyalty: The mediating role of rapport. Journal of Service Management, 24(1), 5-24.

Deng, S., Sinha, A. P., \& Zhao, H. (2017). Adapting sentiment lexicons to domain-specific social media texts. Decision Support Systems, 94, 65-76.

El-Adly, M. I. (2018). Modelling the relationship between hotel perceived value, customer satisfaction and customer loyalty. Journal of Retailing Consumer Services. http://iranarze.ir/wp-content/uploads/2018/09/E9337-IranArze.pdf

Ekinci, Y., Daves, P. L., \& Massey, G. R. (2008). An extended model of the antecedents and consequences of consumer satisfaction for hospitality services. European Journal of Marketing, 42(1/2), 35-68.

Evanschitzky, H., Ramaseshan, B., Woisetschläger, D. M., Richelsen, V., Blut, M., \& Backhaus, C. (2012). Consequences of customer loyalty to the loyalty program and to the company. Journal of the Academy of Marketing Science, 40(5), 625-638.

Fornell, C. (1992). A national customer satisfaction barometer: The Swedish experience. Journal of Marketing, 56(1), 6-21.

Gallarza, M. G., \& Saura, I. G. (2006). Value dimensions, perceived value, satisfaction and loyalty: An investigation of university students' travel behavior. Tourism Management, 27(3), 437-452.

Gremler, D. D., \& Brown, S. W. (1996). Service loyalty: Its nature, importance, and implications. In B. Edwardson, S. W. Brown, and R. Johnston (Eds.), Advancing service quality: A global perspective (pp. 171-180). International Service Quality Association.

Grigoroudis, E., Tsitsiridi, E., \& Zopounidis, C. (2013). Linking customer satisfaction, employee appraisal, and business performance: An evaluation methodology in the banking sector. Annals of Operations Research, 205(1), 5-27.

Gu, H., \& Ryan, C. (2008). Chinese clientele at Chinese hotels Preferences and satisfaction. International Journal of Hospitality Management, 27(3), 337-345.

Gupta, K. K., \& Bansal, I. (2012). Development of an instrument to measure Internet banking service quality in India. International Refereed Research Journal, 2(2), 11-25.

Hallowell, R. (1996). The relationships of customer satisfaction, customer loyalty, and profitability: An empirical study. International Journal of Service Industry Management, 7(4), 27-42.

Heesup, H., Kiattipoom, K., \& Wansoo, K. (2019). Traveler loyalty and its antecedents in the hotel industry. International Journal of Contemporary Hospitality Management, 31(1), 474-495.

Heinonen, K. (2014). Multiple perspectives on customer relationships. International Journal of Bank Marketing, 32(6), 450-456.

Hill, N., \& Alexander, J. (2006). The handbook of customer satisfaction and loyalty measurement (3rd ed.). Aldershot: Gower Publishing, Ltd.

Hwang, J., Han, H., \& Kim, S. (2015). How can employees engage customers? International Journal of Contemporary Hospitality Management, 27(6), 1117-1134.

Ilker, E., Sulaiman, A. M., \& Rukayya, S. A. (2016). Comparison of convenience and purposive sampling. American Journal of Theoretical and Applied Statistics, 5(1), 1-4.

Kandampully, J., \& Suhartanto, D. (2000). Customer loyalty in the hotel industry: The role of customer satisfaction and image. International Journal of Contemporary Hospitality Management, 12(6), 346-351.

Keisidou, E., Sarigiannidis, L., Maditinos, D. I., \& Thalassinos, E. I. (2013). Customer satisfaction, loyalty and financial performance. International Journal of Bank Marketing, 31(4), 259-288.

Keller, K. S. (2003). Strategic brand management: Building, measuring and managing brand equity. Upper Saddle River, NJ: Prentice Hall.

Kesari, B., \& Atulkar, S. (2016). Satisfaction of mall shoppers: A study on perceived utilitarian and hedonic shopping values. Journal of Retailing and Consumer Services, 31, 22-31.

Kim, J. Y., Lee, S., \& Joun, Y. (2016). Green practices of the hotel industry: Analysis through the windows of smart tourism system. International Journal of Information Management, 36(6), 1340-1349.

Khoo-Lattimore, C., \& Ekiz, E. H. (2014). Power in praise: Exploring online compliments on luxury hotels in Malaysia. Tourism Hospitality Research, 14(3), 152-159.

Kwiatek, P., \& Thanasi-Boçe, M. (2019). Loyalty program activity: Make B2B customers buy more. Marketing Intelligence \& Planning, 37(5), 542-554.

Li, H., Ye, Q., \& Law, R. (2012). Determinants of customer satisfaction in the hotel industry: An application of online review analysis. Asia Pacific Journal of Tourism Research, 18(7), 784-802. 
Liu, Y. (2007). The long-term impact of loyalty programs on consumer purchase behavior and loyalty. Journal of Marketing, 71(4), 19-35.

Liu, Y., \& Jang, S. (2009). Perceptions of Chinese restaurants in the U.S.: What affects customer satisfaction and behavioral intentions? International Journal of Hospitality Management, 28(3), 338-348.

Lu, C., Berchoux, C., Marek, M. W., \& Chen, B. (2015). Service quality and customer satisfaction: Qualitative research implications for luxury hotels. International Journal of Culture, Tourism and Hospitality Research, 9(2), 168-182.

Mohsan, F., Nawaz, M., Khan, M., Shaukat, Z., \& Aslam, N. (2011). Impact of customer satisfaction on customer loyalty and intentions to switch: Evidence from banking sector of Pakistan. International Journal of Business and Social Science, 2(16), 263-270.

Mohsin, A., \& Lockyer, T. (2010). Customer perceptions of service quality in luxury hotels in New Delhi, India: An exploratory study. International Journal of Contemporary Hospitality Management, 22(2), 160-173.

Nastasoiu, A., \& Vandenbosch, M. (2019). Competing with loyalty: How to design successful customer loyalty reward programs. Business Horizons, 62(2), 207-214.

Ndubisi, N. O., Malhotra, N. K., \& Chan, K. W. (2009). Relationship marketing, customer satisfaction and loyalty: A theoretical and empirical analysis from an Asian perspective. Journal of International Consumer Marketing, 21(1), 5-16.

Pan, Y., Sheng, S., \& Xie, F. T. (2012). Antecedents of customer loyalty: An empirical synthesis and reexamination. Journal of Retailing and Consumer Services, 19(1), 150-158.

Pesonen, J., Komppula, R., \& Murphy, J. (2019). Plastic loyalty-Investigating loyalty card programs for a Finnish hotel chain. Tourism Management, 73, 115-122.

Phi, D. H., Thanh, P. L., \& Viet, B. N. (2018). Effects of service quality on customer satisfaction and customer loyalty: A case of 4- and 5-star hotels in Ho Chi Minh City, Vietnam. Business and Economic Horizons, 14(3), 437-450.

Pitta, D., Franzak, F., \& Fowler, D. (2006). A strategic approach to building online customer loyalty: Integrating customer profitability tiers. Journal of Consumer Marketing, 23(7), 421-429.

Quan, S. (2010). The relationships among e-service quality, system quality, information quality and customer loyalty: An empirical study of Internet banking in China. Global Journal of Management and Business Research, 10(7), 27-34.

Ramanathan, U., \& Ramanthan, R. (2010). Guests' perceptions on factors influencing customers loyalty: An analysis for UK hotels. International Journal of Contemporary Hospitality Management, 23(1), 7-25.

Raouf Ahmad, R., \& Jyoti, S. (2017). Commitment on customer loyalty: Evidence from the hotel industry. Journal of Hospitality Application \& Research, 12(2), 41-60.

Ren, L., Qiu, H., Wang, P., \& Lin, M. C. P. (2016). Exploring customer experience with budget hotels: Dimensionality and satisfaction. International Journal of Hospitality Management, 52, 13-23.

Ryu, K., Han, H., \& Kim, T. H. (2008). The relationship among overall quick-casual restaurant image, perceived value, customer satisfaction, and behavioural intentions. International Journal of Hospitality Management, 27(3), 459-469.

Ryu, K., Lee, H., \& Kim, W. (2012). The influence of quality of physical environment food and service on restaurant image, customer perceived value, customer satisfaction and behavioural intentions. International Journals of Contemporary Hospitality Management, 24(2), 200-223.

Saks, A. M. (2006). Antecedents and consequences of employee engagement. Journal of Managerial Psychology, 7(21), 600-619.

Santouridis, I., \& Trivellas, P. (2010). Investigating the impact of service quality and customer satisfaction on customer loyalty in mobile telephone in Greece. The TQM Journal, 22(3), 330-343.

Setó-Pamies, D. (2012). Customer loyalty to service providers: examining the role of service quality, customer satisfaction and trust. Total Quality Management, 23(11), 1257-1271.

Shifera, B., \& Apar, S. (2015). Perceived service quality and its relationship with customer loyalty in Ethiopian hotel industry. Journal of Contemporary Research in Management, 10(4), 31-42.

Skogland, I., \& Siguaw, A. J. (2004). Are your satisfied customers loyal? Cornell Hotel and Restaurant Administration Quarterly, 45(3), 221-234.

Slevitch, L., \& Oh, H. (2010). Asymmetric relationship between attribute performance and customer satisfaction: A new perspective. International Journal of Hospitality Management, 29, 559-569.

So, K. K. F., King, C., Sparks, B. A., \& Wang, Y. (2013). The influence of customer brand identification on hotel brand evaluation and loyalty development. International Journal of Hospitality Management, 34, 31-41.

Sun, K. A., \& Kim, D. Y. (2013). Does customer satisfaction increase firm performance? An application of American Customer Satisfaction Index (ACSI). International Journal of Hospitality Management, 35, 68-77. 
Sukhu, A., Choi, H., Bujisic, M., \& Bilgihan, A. (2019). Satisfaction and positive emotions: A comparison of the influence of hotel guests beliefs and attitudes on their satisfaction and emotions. International Journal of Hospitality Management, 77 , 51-63.

Tanford, S., Raab, C., \& Kim, Y. S. (2010). The influence of reward program membership and commitment on hotel loyalty. Journal of Hospitality and Tourism Research, 35(3), 279-307.

Tanford, S., Raab, C., \& Kim, Y. S. (2012). Determinants of customer loyalty and purchasing behavior for full-service and limited-service hotels. International Journal of Hospitality Management, 31(2), 319-328.

Wang, C. Y. (2010). Service quality, perceived value, corporate image, and customer loyalty in the context of varying levels of switching costs. Psychology and Marketing, 27(3), 252-262.

Wicks, A. M., \& Roethlein, C. J. (2009). A satisfaction-based definition of quality. Journal of Business \& Economic Studies, 15(1), 82-97.

Wilkins, H., Merrilees, B., \& Heringtoon, C. (2007). Toward an understanding of total service quality in hotel. International Journal of Hospitality Management, 26(4), 840-853.

World Travel Tourism Council (WTTC). (2018). Travel and tourism: Economic impact 2018 Greece. Retrieved from https://www.wttc.org/-/media/files/reports/economic-impact-research/countries-2018/greece2018.pdf

Wong, E., Leung, R., \& Law, R. (2015). Significance of the dimensions and attributes of hotel mobile website from the perceptions of users. International Journal of Hospitality \& Tourism Administration, 21(1), 15-37.

Wu, M., Pearce, P., \& Dong, W. (2017). How satisfying are Shanghai's superior hotels? The views of international tourists. International Journal of Contemporary Hospitality Management, 29(4), 1096-1115.

$\mathrm{Xu}, \mathrm{X}$. (2020). Examining an asymmetric effect between online customer reviews emphasis and overall satisfaction determinants. Journal of Business Research, 106, 196-210.

Yang, X. F., \& Lau, M. C. V. (2015). Luxury hotel loyalty-A comparison of Chinese gen X and Y tourists to Macau. International Journal of Contemporary Hospitality Management, 27(7), 1685-1705.

Zeithaml, V. A., \& Bitner, M. J. (2003). Services marketing: Integrating customer focus across the firm (3rd ed.). New York: Irwin McGraw-Hill.

Zhao, Y., Xu, X., \& Wang, M. (2019). Predicting overall customer satisfaction: Big data evidence from hotel online textual reviews. International Journal of Hospitality Management, 76, 111-121. 